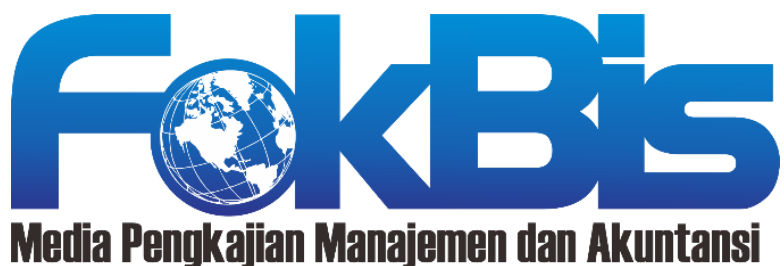

http://journal.stieputrabangsa.ac.id/index.php/fokbis/index

ISSN: 2623-2480/ P-ISSN: 1693-5209

\section{Outlook Internasionalisasi UMKM 2021: Meraih Kesempatan dalam Perlindungan Pasca Pandemi}

\section{Elfan Kaukab}

Fakultas Ekonomi dan Bisnis Universitas Sains Al-Quran Wonosobo, Indonesia email: elfan@unsiq.ac.id

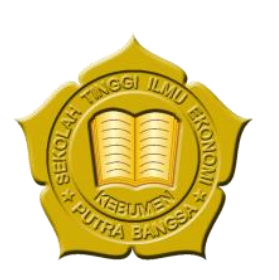

\section{Article Information}

\section{History of Article:}

Received December $18^{\text {th }} 2020$

Accepted December 23 2020

Published December $31^{\text {st }} 2020$

\section{DOI:}

10.32639/fokusbisnis.v19i2.728

\begin{abstract}
ABSTRAK
Pandemi Covid-19 membuat masa depan UMKM di pasar global menjadi lebih tidak pasti. Indonesia adalah salah satu negara dengan jumlah UMKM terbesar dari segi total maupun kepadatan di masyarakat. Dalam artikel ini, sejumlah peristiwa yang terjadi di tahun 2020 digunakan untuk memprediksi masa depan internasionalisasi UMKM di tahun 2021. UU No 11 Tahun 2020 tentang Cipta Kerja, kebijakan social dan physical distancing, keputusan pelarangan impor CPO Uni Eropa, dan kesepakatan Regional Comprehensive Economic Partnership (RCEP) ditinjau. Tinjauan dari keempat kelompok kebijakan ini membawa pada kemungkinan munculnya Peraturan Pemerintah tentang Kemudahan, Perlindungan, dan Pemberdayaan UMK; keberlanjutan dari virtualisasi; perambahan peluang ekspor CPO ke negara-negara IORA dan perbaikan internal industri CPO; serta hadirnya berbagai kerjasama di bidang e-commerce, HAKI, akses pasar, dan inovasi dengan negara-negara ASEAN, Tiongkok, Jepang, Korea Selatan, Australia, dan Selandia Baru. Keberhasilan UMKM dalam meraih peluang dari pasar global ini tergantung dari kemampuan UMKM dalam menjadi pemain sejak awal lewat dukungan pemerintah yang maksimal.
\end{abstract}

Kata Kunci: Internasionalisasi, UMKM, Pandemi Covid-19, Outlook, Omnibus Law

\begin{abstract}
The Covid-19 pandemic has made the future of MSMEs in the global market uncertain. Indonesia is one of the countries with the largest number of MSMEs, both in total and population density. This article uses several issues in 2020 to predict the future of MSMEs internationalization in 2021. It reviews the Omnibus Law no 11 the year 2020, social and physical distancing policies, the European Union's ban of CPO import, and the Regional Comprehensive Economic Partnership (RCEP) agreement. The review leads to the possibility of Government Rule on MSMEs' Ease, Protection, and Empowerment; virtualization continuity; CPO export expansion opportunity to IORA countries and internal improvement. It also brings cooperation in e-commerce, HAKI (intellectual property rights), market access, and innovation with ASEAN countries, China, Japan, South Korea, Australia, and New Zealand. MSMEs' success in seizing the opportunities in the global market depends on their ability to play from the beginning with maximum government support.
\end{abstract}

Keywords: Internationalization, Msmes, Covid-19 Pandemic, Outlook, Omnibus Law 


\section{PENDAHULUAN}

Untuk pertama kalinya dalam sejarah, Musrenbangnas dilakukan secara virtual. Pemerintah telah yakin bahwa tahun 2021 pandemi akan berakhir dan semua rakyat Indonesia, setidaknya yang rentan, telah divaksinasi untuk melindungi diri dari Covid-19. Jelas juga bahwa semua sektor akan mulai menggeliat di tahun 2021 seiring terbukanya kembali ruang untuk menyelenggarakan ekonomi tanpa khawatir dengan penyebaran virus.

Dalam Musrenbangnas 2020, pemerintah telah merencanakan untuk mempercepat tujuh agenda: penguatan ketahanan ekonomi, pengembangan wilayah, peningkatan SDM, peningkatan revolusi mental dan pembangunan kebudayaan, pengutan infrastruktur, pembangunan lingkungan hidup, ketahanan bencana, dan perubahan iklim; dan stabilitas politik hukum dan transformasi public (Media Indonesia, 2020). Semua ini tentunya sebuah gagasan besar yang sulit untuk ditangkap tanpa melihat detail apa saja rencana yang spesifik akan diprogramkan pemerintah. Tetapi setidaknya ada beberapa hal yang cukup pasti dapat terjadi di tahun 2021 dan memberikan dampak yang umumnya positif bagi UMKM dalam kaitannya dengan bisnis global.

\section{DISKUSI}

\section{Peraturan Pemerintah Tentang Kemudahan, Perlindungan, dan Pemberdayaan UMK}

Sebagaimana telah diramalkan pada Outlook 2020 (Kaukab, 2020), tahun 2020 ini Omnibus Law akhirnya diresmikan lewat UU No 11 Tahun 2020 tentang Cipta Kerja. Undang-undang ini sangat besar dengan memuat 1187 halaman pada versi pertama yang diterbitkan pemerintah. Ada kemungkinan bahwa UU ini akan direvisi pada tahun 2021, tergantung keputusan dari Mahkamah Konstitusi.

Jika tetap fokus pada apa yang telah ada sekarang, dapat dilihat bahwa UU Cipta Kerja mengandung beberapa bab isi, yaitu peningkatan ekosistem investasi dan kegiatan berusaha (Bab III), ketenagakerjaan (bab IV), kemudahan, perlindungan, dan pemberdayaan koperasi dan UMKM (bab V), kemudahan berusaha (bab VI), kebijakan fiskal nasional yang berkaitan dengan pajak dan retribusi (bab VIIA), dukungan riset dan inovasi (bab VII), pengadaan tanah (bab VIII), kawasan ekonomi (bab IX), investasi pemerintah pusat dan kemudahan proyek strategis nasional (bab $X$ ), pelaksanaan administrasi pemerintahan untuk mendukung cipta kerja (bab XI), dan pengawasan dan pembinaan (bab XII) (Presiden Republik Indonesia, 2020).

Secara spesifik untuk UMKM, tentunya ada harapan mendapatkan kemudahan dari apa yang dijanjikan di Bab V yang merevisi UU No 20 tahun 2008 tentang UMKM (Presiden Republik Indonesia, 2008). Kemudahan ini ada di pasal 87 yaitu memastikan bahwa BUMN menyediakan pembiayaan dan penyisihan laba tahunan untuk UMK, usaha besar nasional dan asing memberikan alokasi pembiayaan pada UMK, dan pemerintah pusat, pemerintah daerah serta dunia usaha memberikan hibah, mengusahakan bantuan luar negeri, dan mengusahakan sumber pembiayaan lain yang sah dan tidak mengikat untuk UMK, serta pemerintah pusat dan daerah memberikan insentif dalam bentuk kemudahan perizinan, keringanan tarif, dan bentuk lainnya bagi UMK (sebelumnya di UU No 20 tahun 2008 sifatnya hanya sukarela, ditandai dengan kata 'dapat' pada pasal 21. Pada UU Cipta Kerja, hanya kata 'dapat' saja yang dihapus, tetapi ini berimplikasi besar karena berarti jatuh kewajiban, bukan lagi pilihan, bagi pemerintah pusat dan daerah, BUMN, usaha besar nasional dan asing, dan dunia usaha untuk membantu UMKM.

UU Cipta Kerja juga menambah sejumlah pasal baru. Termasuk pasal ini adalah penyediaan basis data tunggal UMKM untuk mendukung kebijakan, dibentuk paling lama tahun 2022 (pasal 88); penataan klaster yang terkait dalam rantai pasok, keterampilan, dan teknologi, dengan kewajiban bagi pemerintah untuk menyediakan fasilitas-fasilitas (ada 10 fasilitas yang wajib disediakan pemerintah, termasuk di antaranya 
pemasaran, digitalisasi, dan litbang) (pasal 89), pengawasan dan evaluasi pelaksanaan kemitraan antara usaha menengah dan besar dengan UMK oleh pemerintah (pasal 90), detail kemudahan perizinan berusaha dimana pendaftaran hanya memerlukan KTP dan keterangan RT (pasal 91), kemudahan fasilitasi pembiayaan dan insentif fiskal (pasal 92-94), pemberian porsi dana alokasi khusus, bantuan dan pendampingan hukum, pengadaan barang dan jasa, dan sistem/aplikasi pembukuan dan inkubasi (pasal 95-102), dan penyediaan ruang usaha bagi UMK pada infrastruktur publik seperti terminal, bandara, pelabuhan, stasiun, rest area, dan lainnya (pasal 103).

Semua ini pada gilirannya dijanjikan akan diatur lebih lanjut dalam Peraturan Pemerintah yang diharapkan dapat muncul di tahun 2021. Hal ini karena pasal 41 UU No 20 Tahun 2008 yang menyatakan bahwa Peraturan Pemerintah pelaksanaan undang-undang ditetapkan paling lambat satu tahun setelah undangundang ini diundangkan, dan pasal ini tidak direvisi pada UU Cipta Kerja. Karenanya, jika pemerintah konsisten, maka di tahun 2021 akan ada PP tentang UMK; banyak bantuan datang dari pemerintah pusat dan daerah, BUMN, usaha besar nasional dan asing, dan dunia usaha, lebih banyak dari tahun-tahun sebelumnya; klaster-klaster bermunculan; dan infrastruktur publik semakin membuka diri bagi UMK.

Perlu dicatat bahwa UU Cipta Kerja hanya memberikan kemudahan pada UMK sementara usaha menengah tidak lagi dibantu, tetapi hal ini tidak berarti usaha menengah yang ada sekarang kehilangan bantuan karena pemerintah akan meredefinisi kriteria usaha pada PP tersebut.

\section{Virtualisasi Meraih Momentumnya dalam Bisnis Akibat Pandemi}

Pandemi adalah masa dimana pemerintah dan dunia usaha mulai mencoba menyelenggarakan virtualisasi secara besar-besaran. Pemerintah sudah memulai dan menyarankan masyarakat untuk bekerja dari rumah. Pertemuan-pertemuan yang biasanya diselenggarakan secara tatap muka tidak lagi menjadi norma, berganti dengan video conferencing (VC) sinkron dengan bantuan aplikasi seperti Google Meet dan Zoom. Apakah mungkin hal ini akan kembali ke zaman tatap muka setelah pandemi usai? Kemungkinan besar yang muncul adalah situasi hibrid, dimana beberapa pertemuan akan diselenggarakan tatap muka sementara pertemuan lain diselenggarakan secara virtual. Lagi pula, virtualisasi jelas menghemat biaya, walau belum tentu meningkatkan produktivitas.

Bagi UMKM, VC memberikan manfaat sekaligus juga kerugian. Studi Hardwick dan Anderson (2019) cukup mendalam mengenai bagaimana dinamika hubungan antara pemasok dan buyer dalam komunikasi menggunakan VC, terlebih karena studi ini kualitatif (Hardwick \& Anderson, 2019). Sudah cukup jelas apa manfaat VC bagi bisnis: menghilangkan jarak (dan karenanya biaya perjalanan) dan juga tidak membuang waktu. Tetapi di saat yang sama, ada hal yang patut digaris bawahi mengenai kelemahan VC dalam bisnis: pertemuan tatap muka lebih interaktif dan kaya daripada VC. Hal ini penting terutama bagi transaksi yang kompleks atau memerlukan kepercayaan besar. Lewat VC tidak dapat menunjukkan sampel secara fisik, kecuali jika sampel tersebut telah dikirim sebelumnya ke tangan buyer. Tampilan melalui VC juga tidak memungkinkan pandangan tiga dimensi terhadap produk, sehingga kepercayaan buyer pada produk mungkin akan terbatas dibandingkan tatap muka. Lagi pula, VC paling efektif jika kita telah mengenal buyer dan buyer telah mengenal penjual. Sebagian memandang bahwa komunikasi tatap muka adalah pemicu hubungan jangka panjang antara pembeli dan penjual. Sebagai contoh, dalam VC tidak dapat bercerita tentang keluarga atau latar belakang personal, sementara pada tatap muka, hal ini lumrah sebagai bagian dari proses saling mengenal. Dan lebih dari itu, ada faktor teknis terkait jaringan internet dan visualisasi yang terpatah-patah yang membuat para peserta mengalami teknostress jika dilakukan tanpa henti dalam waktu yang panjang.

Masyarakat Indonesia adalah masyarakat pencoba yang antusias pada teknologi informasi. Besar kemungkinan bahwa tahun 2021, kita akan melihat banyak aktivitas diselenggarakan lewat VC. Pelaku usaha sebaiknya tetap memberikan opsi tatap muka atau melalui VC sehingga kedua belah pihak dapat nyaman dengan transaksi bisnis. 


\section{Saatnya Membenahi UMKM Sawit dan Meraih Peluang Pasar Baru}

Isu yang mengkhawatirkan UMKM di tahun 2021 adalah ditundanya pelarangan impor minyak sawit CPO Indonesia dan Malaysia oleh Uni Eropa. Sebenarnya diagendakan oleh Uni Eropa di tahun 2021 kalau Uni Eropa mulai melarang sawit dari Indonesia. Walau begitu, setelah negosiasi cukup melelahkan, akhirnya diputuskan bahwa larangan sawit ditunda tahun 2030 tapi reduksi akan dimulai sejak tahun 2024.

Patut bersyukur kalau Uni Eropa menunda pelarangan impor sawit hingga 2030. Ada pertentangan pendapat mengenai dampak larangan ini jika diterapkan di tahun 2021. Para peneliti UGM menyimpulkan akan ada reduksi GDP nyata Indonesia sebesar 7,66\% akibat pelarangan impor sawit bagi Indonesia (Pratama \& Widodo, 2020). Sementara itu, para peneliti IPB memandang bahwa larangan tersebut tidak akan berdampak signifikan pada ekonomi Indonesia (Rifin, Feryanto, Herawati, \& Harianto, 2020). Perbedaan ini tampaknya disebabkan pada penggunaan tahun dasar analisis. Analisis UGM menggunakan data dasar tahun 2011 sementara analisis IPB menggunakan data dasar 2004, 2007, dan 2011. Karenanya, walaupun metode analisis dan data yang digunakan sama, tetapi hasil yang diperoleh jauh berbeda.

Tabel 1. Perbedaan Peramalan Dampak Ekonomi Larangan Sawit Uni Eropa

\begin{tabular}{|c|c|c|}
\hline & UGM (Pratama dan Widodo, 2020) & IPB (Rifin et al, 2020) \\
\hline Reduksi GDP & $-7.66 \%$ & $-0,00274 \%$ \\
\hline Tahun dasar & 2011 & 2004, 2007, dan 2011 \\
\hline Justifikasi & Tidak disebutkan & $\begin{array}{l}\text { Konsisten dengan penelitian } \\
\text { oleh Kementerian Industri } \\
\text { tahun } 2018\end{array}$ \\
\hline $\begin{array}{l}\text { Sektor paling } \\
\text { parah } \\
\text { terdampak }\end{array}$ & $\begin{array}{l}\text { Livestock and meat products }(-1,5 \%) \text {, } \\
\text { processed food }(-0,74 \%) \text {, utilities and } \\
\text { construction }(-1,1 \%) \text {, transport and } \\
\text { communication }(-0,28 \%) \text {, other services } \\
(-3,21 \%)\end{array}$ & $\begin{array}{l}\text { Unskilled labor }(-4,86) \text {, skilled } \\
\text { labor }(-4,82) \text {, output }(-4,79) \text {, } \\
\text { land }(-2,33) \text {, price }(-0,10)\end{array}$ \\
\hline
\end{tabular}

Sumber: data diolah, 2020

Entah itu hasilnya negatif atau tidak signifikan, memang perlu berbenah pada permasalahan sawit Indonesia. Uni Eropa melarang sawit Indonesia atas alasan pelanggaran hak asasi manusia, korupsi, pekerja anak, kerusakan lingkungan, pembabatan hutan, dan penghilangan hak-hak masyarakat adat. Tahun 2021 dapat dianggap sebagai momen bagi pelaku usaha di bidang sawit untuk mulai memperbaiki diri, bahkan seandainya tuduhan tersebut tidak berdasar dan hanya untuk alasan politis. Para pengusaha sawit, sembari memperbaiki diri pada aspek-aspek di atas, juga perlu segera mencari pasar lain yang potensial untuk mengantisipasi penurunan permintaan dari Uni Eropa. Selain itu, dapat pula memanfaatkan kerjasama IORA (Indian Ocean Rim Association) dengan segala kemudahannya untuk memulai ekspor CPO ke pasar-pasar baru di Afrika. Selain itu, pasar dalam negeri juga dapat mendorong lewat pemanfaatan minyak sawit untuk bahan bakar biodisel, alih-alih untuk makanan dan minuman. Pemerintah pada bulan Juli 2021 berencana akan mulai menggunakan bahan bakar dari sawit B40 untuk kendaraan bermotor, di saat yang sama akan menghapus premium dari pasar BBM (VIO, 2020). Intinya adalah perlu ada perbaikan ke dalam dan ke luar guna merespon larangan impor Uni Eropa terhadap minyak sawit Indonesia. Dengan adanya kemudahan-kemudahan yang diberikan pada UMKM lewat UU Cipta Kerja, semestinya hal ini akan lebih mudah bagi UMKM di Indonesia. 


\section{Peluang dari RCEP}

Per tanggal 15 November 2020, Indonesia bersama negara-negara ASEAN, Tiongkok, Jepang, Korea Selatan, Australia, dan Selandia Baru menyepakati Regional Comprehensive Economic Partnership (RCEP). Sesuai namanya, RCEP mencakup kemitraan ekonomi yang menyeluruh antara negara-negara yang menanda tanganinya. Mengingat negara-negara ini mencakup 30\% populasi dunia, 32\% GDP global, 30\% FDI global, dan 27,4\% perdagangan global (Jakarta Globe, 2020), maka RCEP dapat dikatakan sebagai bentuk kerjasama regional terbesar saat ini. Tujuan RCEP adalah membangun kemitraan ekonomi saling menguntungkan yang modern, komprehensif, dan bermutu tinggi yang memfasilitasi perkembangan investasi dan perdagangan regional serta berkontribusi pada pertumbuhan ekonomi global. RCEP mengklaim akan meningkatkan kesempatan bisnis dan memberikan peluang ketenagakerjaan di negaranegara anggotanya. Menurut Kementerian Perdagangan, RCEP akan meningkatkan GDP tahun 2021-2032 sebesar $0,05 \%$, dibandingkan tanpa RCEP yang justru turun $0,07 \%$.

Bagi UMKM, dokumen final RCEP menawarkan banyak kesempatan. Berikut bagian dari perjanjian RCEP yang berurusan dengan UMKM:

The Parties recognize that SMEs, including micro enterprises, contribute significantly to economic growth, employment, and innovation and therefore seek to promote information sharing and cooperation in increasing SMEs' ability to utilize and benefit from the opportunities created by the RCEP Agreement. This Chapter obliges the Parties to promote sharing of RCEP-related information relevant to SMES by establishing and maintaining a publicly accessible information platform that will contain the full text of the RCEP Agreement, trade and investment-related laws and regulations pertinent to SMEs, and other business-related information that would be useful for SMEs to benefit from the RCEP Agreement. This Chapter also aims to strengthen cooperation in the areas of e-commerce, intellectual property rights, access to markets, and innovation, among others (ASEAN, 2020).

Dari kutipan di atas, dapat dilihat bahwa perjanjian RCEP akan menguntungkan UMKM dengan mendorong berbagi informasi dan kerjasama dalam meningkatkan kemampuan UMKM untuk meraih manfaat dari RCEP. Hal ini dilakukan dengan (1) menyediakan platform publik untuk mendukung UMKM memahami secara regulasi segala peraturan terkait UMKM yang berasal dari RCEP, dan (2) meningkatkan kerjasama di bidang e-commerce, HAKI, akses pasar, inovasi, dan sebagainya.

Kutipan di atas terkesan terlalu luas, tetapi tentunya tidak diharapkan bahwa dokumen kerjasama regional akan spesifik dalam menjabarkan program-programnya. Walau bagaimanapun, secara garis besar dapat dikatakan bahwa ke depannya, UMKM Indonesia akan lebih mudah memasarkan produknya ke negara ASEAN, Tiongkok, Jepang, Korea Selatan, Australia, dan Selandia Baru dibandingkan ke negaranegara lain seperti IORA, Uni Eropa, Amerika, Asia Barat, Asia Tengah, dan Asia Selatan. Tetapi tentu saja, UMKM dari negara-negara anggota RCEP juga lebih mudah memasarkan produk di Indonesia. Akibatnya, hal ini kembali kepada kemampuan internal UMKM untuk memanfaatkan secara maksimal fasilitas yang diberikan pemerintah Indonesia lewat RCEP tersebut serta kekuatan dan kesempatan yang disediakan. RCEP jelas adalah sebuah kesempatan, lalu bagaimana dengan kekuatan Indonesia?

Pertama, Indonesia adalah negara dengan penduduk kedua terbesar dalam RCEP setelah Tiongkok. Kedua, hampir beriringan dengan RCEP, Indonesia telah mengeluarkan UU Cipta Kerja yang memudahkan UMK dan karenanya, kita memiliki mulai awal yang sangat baik. Ketiga, UMKM kita adalah yang terbanyak di dunia, bukan saja di lingkungan RCEP dan ranking ini bukan semata berdasarkan jumlah tetapi juga ratarata per 1000 penduduk. Tabel dari Nationmaster menunjukkan negara kedua dengan jumlah UMKM terbanyak di dunia tak sampai setengahnya Indonesia (Nationmaster, 2006). Tabel dari tahun 2000an ini relatif dapat dipercaya mengingat data 2020 juga menunjukkan kalau nilai yang diperoleh relatif sama. 
Tabel 2. Jumlah UMKM Negara-Negara Anggota RCEP

\begin{tabular}{lccc}
\hline Negara & Jumlah UMKM & Tahun Data & Jumlah per 1000 penduduk \\
\hline Brunei & 5,900 & 2017 & 14 \\
Kamboja & 460,000 & 2019 & 30 \\
Indonesia & $64,194,000$ & 2020 & 358 \\
Laos & 114,200 & 2006 & 17 \\
Malaysia & 907,100 & 2016 & 30 \\
Myanmar & 114,200 & 2015 & 2 \\
Philipina & 998,300 & 2018 & 10 \\
Singapura & 271,800 & 2019 & 49 \\
Thailand & $3,077,800$ & 2018 & 45 \\
Vietnam & 744,800 & 2019 & 8 \\
Tiongkok & $18,070,000$ & 2019 & 13 \\
Jepang & $3,500,000$ & 2017 & 68 \\
Korea Selatan & $3,500,000$ & 2014 & 81 \\
Australia & $2,065,523$ & 2016 & 33 \\
Selandia Baru & 160,000 & 2018 & \\
\hline Total & $98,183,623$ & & $2016 ;$
\end{tabular}

Sumber: Australian Small Business and Family Enterprise Ombudsman, 2016; Government of New Zealand, 2019; KOSME Global Cooperation Dept, 2015; Organization for Small \& Medium Enterprises and Regional Innovation Japan, 2017; Schaper, 2020; United Nations Population Div, 2020; Xinhua, 2019.

Outlook ini tidak akan membahas lebih jauh tentang kelemahan dan ancaman seperti pada analisis SWOT pada umumnya. Sebagian akademisi memandang bahwa dengan menunjukkan W (weakness) dan T (threat) membuat kita cenderung defensif dan pasif (Zarestky \& Cole, 2017). Masalahnya, kita secara psikologis lebih cenderung untuk fokus pada risiko atau hal-hal negatif daripada hal-hal positif, bahkan seandainya keduanya dijabarkan secara seimbang (Pachur, Schulte-Mecklenbeck, Murphy, \& Hertwig, 2018) Sebaiknya, dengan telah adanya Strength dan Opportunities, yang perlu dianalisis adalah Aspirasi yang dimiliki dan results yang diinginkan. Apa yang kemudian ingin diwujudkan dan apa hasil yang akan dicapai. Hal ini akan membuat lebih aktif dalam merespon lingkungan yang ada.

\section{REFERENSI}

ASEAN. Summary of the Regional Comprehensive Economic Partnership Agreement (2020).

Australian Small Business and Family Enterprise Ombudsman. (2016). Small Business Counts: Small Business in the Australian Economy. Canberra.

Government of New Zealand. (2019). Small businesses record sales of \$ 153 billion in 2018.

Hardwick, J., \& Anderson, A. R. (2019). Supplier-customer engagement for collaborative innovation using video conferencing : A study of SMEs. Industrial Marketing Management, (December 2016), 1-15. https://doi.org/10.1016/j.indmarman.2019.02.013

Jakarta Globe. (2020, November). Indonesia Eyes Multiple Benefits from RCEP. Jakarta Globe.

Kaukab, M. E. (2020). Indonesian Economic Outlook 2020 : Peluang dari Keterbukaan. Jurnal Penelitian Dan Pengabdian Kepada Masyarakat, 7(1), 38-47.

KOSME Global Cooperation Dept. (2015). Yearly Trends of SMEs. 
Media Indonesia. (2020, April). Bappenas: Ada 7 Prioritas Nasional di 2021. Media Indonesia.

Nationmaster. (2006). Per capita : Countries Compared.

Organization for Small \& Medium Enterprises and Regional Innovation Japan. (2017). Message from Chairman / CEO.

Pachur, T., Schulte-Mecklenbeck, M., Murphy, R. O., \& Hertwig, R. (2018). Prospect Theory Reflects Selective Allocation of Attention. Journal of Experimental Psychology: General, 147(2), 147-169.

Pratama, R. A., \& Widodo, T. (2020). The Impact of Nontariff Trade Policy of European Union Crude Palm Oil Import on Indonesia, Malaysia, and the Rest of the World Economy : An Analysis in GTAP Framework. Jurnal Ekonomi Indonesia, 9(1), 39-52.

Presiden Republik Indonesia. Undang-Undang Republik Indonesia Nomor 20 Tahun 2008 tentang Usaha Mikro, Kecil, dan Menengah (2008).

Presiden Republik Indonesia. Undang-Undang Republik Indonesia Nomor 11 Tahun 2020 tentang Cipta Kerja (2020).

Rifin, A., Feryanto, Herawati, \& Harianto. (2020). Assessing the impact of limiting Indonesian palm oil exports to the European Union. Journal of Economic Structures, 9(26), 1-13. https://doi.org/10.1186/s40008-020-00202-8

Schaper, M. T. (2020). The Missing ( Small ) Businesses of Southeast Asia. Singapore.

United Nations Population Div. (2020). Countries in the world by population ( 2020 ).

VIO. (2020, July). Bahan Bakar dari Sawit B40 Siap Digunakan Kendaran Bermotor pada Juli 2021. VOI.

Xinhua. (2019). Report : China's SMEs important contributors to economy.

Zarestky, J., \& Cole, C. S. (2017). Strengths, opportunities, aspirations, and results : An emerging approach to organization development. New Horizons in Adult Education \& Human Resource Development, 29(1), 5-19. 